\title{
ANALISIS THE FIVE FORCES STRATEGY PADA AL-MUMTAZ PEDULI PONTIANAK
}

\author{
Ichsan Iqbal \\ Institut Agama Islam Negeri (IAIN) Pontianak \\ e-mail: ichsaniqbal26@yahoo.com
}

\begin{abstract}
This study discussed the implementation of the strategy management system on zakat management organizations 'Al-Mumtaz Peduli' Pontianak, West Kalimantan. Using the Five Forces Strategy analysis, the researcher will see to what extent Al-Mumtaz Peduli Pontianak is able to serve its function as a zakat agency competing with other organizations. This study was a field and qualitative research. The data had been obtained through interviews and documentation. This study concludes that Al-Mumtaz Peduli recognized other zakat institutions are partners that can work together to alleviate poverty and social problems. AlMumtaz gives services on orphans and wish every village has a religious preacher. Al-Mumtaz Peduli always do a socialization through seminars, mass and electronic media. Relating with collection and distribution of ZISWAF funds, AlMumtaz always improves its services to muzakki by giving activity and financial reports socialized by a per-three months' magazines.
\end{abstract}

Penelitian ini membahas implementasi sistem manajemen strategi pada organisasi pengelola zakat 'Al-Mumtaz Peduli' Pontianak, Kalimantan Barat. Dengan menggunakan analisa Five Forces Strategy, peneliti akan melihat sejauh mana Al-Mumtaz Peduli Pontianak mampu menjalankan fungsinya sebagai organisasi pengelola zakat ditengah persaingan dengan lembaga zakat yang lain. Penelitian ini merupakan penelitian lapangan dan kualitatif. Sedangkan data didapatkan melalui wawancara dan dokumentasi. Penelitian ini menyimpulkan bahwa Al-Mumtaz Peduli memandang organisasi pengelola zakat yang lain adalah mitra, supaya dapat bersinergi dalam mengentaskan kemiskinan social problem. Al-Mumtaz fokus segmen layanannya pada anak yatim dan berharap setiap desa ada memiliki satu dai. Al-Mumtaz Peduli harus selalu melakukan sosialisasi, baik melalui seminar, media massa dan elektronik. Dalam hal pengumpulan dan penyaluran dana ZISWAF dan Al-Mumtaz selalu meningkatkan pelayanan kepada muzakki berbentuk laporan kegiatan dan keuangan berbentuk majalah yang disampaikan per tri wulan.

Keywords: $\quad$ zakat; Al-Mumtaz Peduli; Five Forces Strategy; zakat agencies 


\section{A. Pendahuluan}

Profesionalisme pada organisasi pengelola zakat sesungguhnya mempunyai makna yang sangat luas dan mendalam. Seorang atau lembaga yang dipandang profesional setidaknya ditandai oleh beberapa karakteristik antara lain: kecakapan (kompetensi teknis dan manajemen), pendidikan sesuai dengan standar yang ditentukan, gaji atau penghasilan yang memadai, keterikatan pada asosiasi profesi yang berhak mengeluarkan lisensi operasional, ketaatan pada etika (profesi), totalitas dalam waktu (tidak sambilan), keterbukaan (transparansi). ${ }^{1}$ Karakteristik-karakteristik tersebut apabila diterapkan pada lembaga zakat yang beroperasi maka sangat mungkin yang memenuhi persyaratan sangat sedikit. Padahal, profesionalisme lembaga zakat amat penting dimata para muzakki yang akan menitipkan zakatnya

Muzakki membayarkan zakat kepada lembaga zakat yang dikelola dengan baik, hal ini memiliki manfaat-manfaat ${ }^{2}$ antara lain: 1) kelompok masyarakat yang lemah dan kekurangan, tidak merasa sendirian, sebaliknya mereka merasa hidup ditengah manusia yang beradab, memiliki nurani, kepedulian dan tradisi yang saling menolong; 2) Para muzakki lebih disiplin dalam menunaikan kewajiban dan kaum fakir miskin lebih terjamin haknya. 3) Perasaan fakir miskin lebih terjaga, karena dia tidak lagi seperti peminta-minta. 4) Distribusinya akan lebih tertib dan teratur. 5) Peruntukkan bagi kepentingan umum, seperti fi sabilillah, dapat disalurkan dengan baik, karena pemerintah lebih mengetahui sasaran pemanfaatannya. 6) Zakat dapat mengisi perbendaharaan negara. 7) Zakat dapat digunakan untuk mengelola dan mengembangkan potensi-potensi ekonomi rakyat yang bersifat produktif. 8) Menghilangkan rasa rikuh dan canggung yang mungkin dialami mustahiq ketika berhubungan dengan muzakki.

\footnotetext{
1M. Akhyar Adnan "Kelembagaan Zakat" dalam Hertanto Widodo dan Teten Kustiawan, Akuntansi \& Manajemen Keuangan untuk Organisasi Pengelola Zakat (Jakarta: IMZ, 2001), h. xiv.

2M. Djamal Doa, Menggagas Pengelolaan Zakat oleh Negara, (Jakarta: Nuansa Madani, 2001), h. 1630. Lebih lanjut diungkapkan Juwaini bahwa pentingnya lembaga zakat, antara lain: 1). Dapat mengkikis sikap egoisme muzakkī, yang seolah memandang harta zakat adalah miliknya semata, 2) tidak akan terjadi proses perendahan mustahiq, karena mustahiq tidak secara langsung berhubungan dengan muzakki, 3) supaya terjadi pemerataan, keadilan dan ketepatan sasaran, 4) Menghindari rasa ketidakadilan masyarakat manakala dana besar diberikan kepada satu atau dua orang, 5) supaya dapat dimobilisasi dan didayagunakan untuk keperluan strategis umat. Lihat Ahmad Juwaini, "Ketika Zakat ditunaikan Melalui Lembaga", dalam Zakat dan Peran Negara (Jakarta: FOZ, 2006), h. 25.
} 
Zakat sebagai suatu kekuatan yang aktual umat Islam perlu dikelola dengan suatu siklus sistem manajemen strategi yang baik. Siklus sistem manajemen strategi yang baik mempertimbangkan faktor menyusun strategi dengan memperhatikan faktor visi, misi dan nilai, merencanakan strategi menggunakan analisis-analisis seperti PESTEL (political, economic, social, technological, environmental dan legal), analisa SWOT (Strength, Weaknesses, Opportunities, Threats), balanced scorecard, the five force strategy dan melakukan evaluasi.

Perusahaan juga dapat melakukan analisa pendekatan the five force strategy, memperhatikan hal yang berhubungan dengan persaingan diantara perusahaan yang ada, kekuatan penawaran pemasok, kekuatan penawaran pembeli, ancaman pendatang baru, pesaing-pesaing yang ada dan ancaman produk dan jasa pengganti ${ }^{3}$.

Rivalitas diantara pesaing yang ada berbentuk pelombaan untuk mendapatkan posisi dengan menggunakan taktik-taktik seperti persaingan harga, perang iklan, introduksi produk, dan meningkatkan pelayanan atau jaminan kepada pelanggan. Persaingan yang tajam merupakan akibat dari sejumlah faktor-faktor struktural yang saling berinteraksi, antara lain: jumlah pesaing yang banyak, pertumbuhan industri yang lambat, biaya tetap yang tinggi, ketiadaan diferensiasi, penambahan kapasitas yang besar, pesaing yang beragam, taruhan strategis yang besar dan hambatan pengunduran diri yang tinggi. ${ }^{4}$

Ada beberapa kesalahan umum yang berhubungan dengan strategi pemanfaatan sumber daya yang biasa dilakukan oleh perusahaan ${ }^{5}$ antara bin; para manajer cenderung melebih-lebihkan pengalihan asset tertentu dan kemampuan, manajer melebih-lebihkan kemampuan mereka untuk bersaing dalam industri yang sangat menguntungkan, mengasumsikan bahwa manfaat sumber daya generik $^{6}$ akan menjadi sumber utama keunggulan kompetitif dalam pangsa pasar yang baru. Perumusan strategi dalam perusahaan dapat membuat sebuah strategi

${ }^{3}$ Michael E. Porter, Competitive Strategy: Techniques for Analyzing Industries and Competitors, (Boston: Macmillan Publishers, 1980), h. 5.

4Michael E. Porter, Competitive Strategy..., h. 6-28. Lihat juga Mason A. Carpenter dan Gerand Sander, Strategic Management: A Dynamic Perspective, (New Jersey: Pearson Education, 2009), h. 142-153.

5Collis, “Competing on Resources", Harvard Business Review, 86 No. 6, 2008, h. 150.

${ }^{6}$ Sumber daya generik ada tiga yakni: keunggulan biaya, diferensiasi dan fokus. Michael E. Porter, Competitive Advantage: Creating and Sustaining Superior Performance, (Boston: Macmillan Publishers, 1985), h. 11. 
yang berhubungan dengan pangsa pasar, proposisi nilai yang membedakan perusahaan dalam pandangan konsumen, membuat proses kunci untuk perbedaan pada strategi, kapasitas SDM yang diperlukan oleh strategi dan teknobgi. ${ }^{7}$

Sistem manajemen strategi digunakan untuk mendukung kegiatan manajemen dengan mengorganisasikan kegiatan perzakatan dalam satuan-satuan kerja yang mudah dikoordinasikan, direncanakan, dilaksanakan dan dievaluasi. Pengorganisasian kegiatan perzakatan dilaksanakan melalui berbagai fungsi kelembagaan yang akan diciptakan untuk itu seperti fungsi pengumpulan dan penyimpanan zakat, fungsi penyaluran zakat dan pembinaan ekonomi umat, fungsi evaluasi, penelitian dan pengembangan kegiatan perzakatan yang efektif.

Organisasi pengelola zakat yang terdapat di Kalimantan Barat baik badan 'āmil zakat dan lembaga 'āmil zakat, antara lain Badan Amil Zakat Nasional (BAZNAS) Provinsi Kalbar, Dompet Ummat, Al-Mumtaz Peduli, Rumah Zakat Cabang Kalbar masih belum optimal dalam menerapkan Sistem manajemen strategi. kasus ini juga menimpa lembaga Al-Mumtaz Peduli yang memiliki cabang hampir diseluruh kota di Kalimantan Barat. Hal ini membuat peneliti tergerak untuk menjadikan Al-Mumtaz Peduli sebagai objek penelitian, dimana Al-Mumtaz Peduli merupakan lembaga 'āmil zakat yang besar dan memiliki pengaruh yang luas di Kalimantan Barat. Penelitian ini akan membahas penerapan sistem manajemen strategi pada organisasi pengelola zakat yang dalam hal ini adalah Al-Mumtaz Peduli. Dengan menggunakan analisa Five Forces Strategy, peneliti akan melihat sejauh mana Al-Mumtaz Peduli Pontianak mampu menjalankan fungsinya sebagai organisasi pengelola zakat ditengah persaingan dengan lembaga zakat yang lain. Penelitian ini merupakan penelitian kualitatif dan lapangan. Sedangkan data didapatkan melalui wawancara dengan berbagai informan dari pihak manajemen Al-Mumtaz Peduli Pontianak.

\section{B. Analisa The Five Forces Strategy}

Pengorganisasian merupakan sebuah proses mengatur dan mengabkasikan pekerjaan, wewenang dan sumber daya diantara anggota organisasi,

\footnotetext{
7Michael E. Porter, “What is Strategy?", Harvard Business Review, November-December 1996, h. 63. Lihat juga Michael A. Hitt and R. Duane Ireland, Strategic Management: Competitiveness and Globalization, (Ohio: South-Westren College Publishing, 2001), h. 63-65.
} 
sehingga dapat mencapai tujuan organisasi. Sasaran yang berbeda memerlukan struktur yang berbeda pul. Para manajer harus menyesuaikan struktur organisasi dengan sasaran dan sumber daya, sebuah proses yang disebut dengan desain organisasi. Hubungan (relasi) dan waktu menjadi hal yang sentral untuk mengorganisasikan aktivitas. Pengorganisasian menghasilkan struktur hubungan dalam sebuah organisasi dan melalui hubungan terstruktur inilah rencana masa depan akan tercapai. Aspek lain dari hubungan yang merupakan bagian dari pengorganisasian adalah mencari orang-orang baru untuk menggabungkan struktur hubungan dalam organisasi.

Kepemimpinan merupakan suatu aktivitas yang meliputi mengarahkan, mempengaruhi dan memotivasi karyawan untuk melaksanakan tugas yang penting. Memimpin menyentuh hubungan manajer dengan setiap orang yang bekerja dengan perusahaan. Para manajer memimpin untuk mempengaruhi orang lain supaya mau bergabung dengan perusahaan dalam mencapai masa depan yang muncul dari langkah merencanakan dan mengorganisasikan.

Menurut Gluck, manajemen strategis dalam perusahaan akan berkembang melalui 4 (empat) tahapan yang berurutan yaitu: pertama, perencanaan keuangan dasar: mencari pengendalian operasional yang lebih baik melalui pemenuhan anggaran. Kedua, perencanaan berbasis perkiraan: mencari perencanaan yang lebih efektif untuk pertumbuhan dengan mencoba meramalkan yang akan datang, melebihi dari tahun berikutnya. Ketiga, perencanaan berorientasi keluar (perencanaan strategis): mencari cara untuk meningkatkan respon terhadap pasar dan persaingan dengan mencoba berpikir secara strategis. Keempat, manajemen strategis: mencari cara untuk mengelola semua sumber daya guna mengembangkan keunggulan kompetitif dan membantu menciptakan kesuksesan di masa yang akan datang. 8

Implementasi strategi mensyaratkan perusahaan untuk menetapkan tujuan tahunan, membuat kebijakan, memotivasi karyawan dan mengabkasikan sumber daya sehingga strategi yang telah diformulasikan dapat diterapkan. Implementasi strategi meliputi mengembangkan budaya yang mendukung

8F.W. Gluck, S. Hal Kaufman and A.S. Wallack, "The Four Phases of Strategic Management", Journal of Business Strategy ,1992, h. 9-21, diakses pada tanggal 7 Desember 2014. 
strategi, menciptakan struktur organisasi yang efektif dan mengarahkan usaha pemasaran, menyiapkan anggaran, mengembangkan dan memberdayakan sistem informasi dan menghubungkan kinerja karyawan dengan kinerja perusahaan.

Evaluasi strategi merupakan tahap final dalam manajemen strategi. Manajer ingin mengetahui kapan strategi tidak dapat berjalan sesuai yang diharapkan. Evaluasi strategi adalah alat utama untuk mendapatkan informasi ini. ${ }^{9}$ Semua strategi dapat dimodifikasi di masa datang karena faktor internal dan eksternal secara konstan berubah. Ada tiga aktivitas dasar evaluasi strategi, yaitu: 1) meninjau ulang faktor eksternal dan internal yang menjadi dasar strategi saat ini; 2) mengukur kinerja; dan 3) mengambil tindakan korektif.

Evaluasi strategi ini menjadi sangat penting bagi sebuah organisasi karena kesuksesan hari ini tidak menjamin kesuksesan hari esok ${ }^{10}$

Sumber daya yang memenuhi syarat sebagai dasar untuk strategi efektif, ia harus melalui beberapa tes dari pasar eksternal terhadap nibinya, tes ini kadangkala disalahpahami atau disalahgunakan yang berakibat macetnya sebuah strategi, terdiri dari ujian inimitability, ujian daya tahan, ujian ketepatan waktu, ujian substitusi dan ujian keunggulan kompetitif. Ujian inimitability memiliki karakter, antara lain: keunikan fisik dan menciptakan loyalitas. Ujian inimitability adalah inti dari penciptaan nibi karena adanya batas persaingan. Jika sumber daya tidak dapat ditiru, maka setiap aliran itu menghasilkan keuntungan lebih lama. Pesaing memiliki sumber daya dengan mudah dapat meniru hanya menghasil nilai sementara. Karena manajer gagal menerapkan tes ini secara seksama, mereka mencoba untuk membuat strategi jangka panjang dengan sumber daya yang meniru. Inimitablity tak akan berlangsung selamanya, pesaing pada akhirnya akan menemukan cara meniru sumber daya yang paling berharga.

Ujian daya tahan mempertanyakan apakah sumber daya bisa mempertahankan keunggulan kompetitif dari waktu ke waktu. Dalam hal yang berkenaan dengan ujian daya tahan, tidak semua keuntungan sumber daya secara otomatis

${ }^{9}$ P. Grinzer and P. Mckiernan, "Generating Major Change in Stagnating Companies", Strategic Management Journal, 1990, h. 131-146. http://www.interscience.wiley.com/journal/2144/ome/ ForAuthors.html. diakses pada tanggal 8 Desember 2014.

${ }^{10}$ David J. Hunger and Thomas L. Wheelen, Strategic Management (New Jersey: Addison-Wesley Publishing, 1996), h. 8. 
ke perusahaan yang memiliki sumber daya. Bahkan, nilai selalu pada tawarmenawar di antara sejumlah pemain, termasuk pelanggan, distributor, pemasok dan karyawan. Berkenaan dengan ujian substitusi, sejak diperkenalkan the five competitive forces, setiap strategi telah mewaspadai dampak potensial dari produk-produk pengganti. Dalam hal berhubungan ujian keunggubn kompetitif, mungkin kesalahan manajer terbesar adalah ketika mengevaluasi perusahaan sumber daya mereka adalah bahwa mereka tidak menilai relatif terhadap pesaing. ${ }^{11}$

Analisa eksternal meliputi pengujian level industri dari ekonomi industri, seperti Michael Porter's five forces strategy: kekuatan penawaran dari pembeli, kekuatan penawaran dari penyalur, kekuatan barang pengganti, ancaman dari pendatang baru dan persaingan industri. ${ }^{12}$ Strategi ini dikenal dengan nama The Five Forces Strategy (Strategi Lima keunggulan). ${ }^{13}$

Perusahaan yang menghasilkan produk atau jasa, aturan persaingan dicakup didalam lima kekuatan bersaing, yakni masuknya pesaing baru, ancaman dari produk pengganti (substitusi), kekuatan penawaran (tawar-menawar) pembeli, kekuatan penawaran pemasuk dan persaingan diantara pesaingpesaing yang ada. Strategi ini dikenal dengan nama The Five Forces Strategy.

The Five Forces Strategy menjelaskan dalam kasus munculnya pendatang baru pada suatu industri membawa kapasitas baru, keinginan untuk merebut pasar, serta seringkali juga sumber daya yang besar. Akibatnya harga dapat menjadi turun atau biaya membesar sehingga mengurangi kemampuan menghasilkan laba. Ada beberapa rintangan yang masuk bagi pendatang baru, yaitu: skala ekonomis, diferensiasi produk, kebutuhan modal, biaya beralih pemasok, akses kesaluran distribusi, biaya tak menguntungkan terlepas dari skala dan kebijakan pemerintah. Semua perusahaan dalam suatu industri bersaing, dalam arti yang luas, dengan industri-industri yang menghasilkan produk pengganti.

\footnotetext{
11David J. Collis, “Competing on Resources”, Harvard Business Review , Vol. 86 No. 6, July-August 2008, h. 143-147.

${ }^{12}$ Michael. E. Porter, "The Five Competitive Forces That Shape Strategy", Harvard Business Review, January 2008, h. 86-87.

${ }^{13}$ Michael E. Porter, Competitive Strategy..., h. 4.
} 


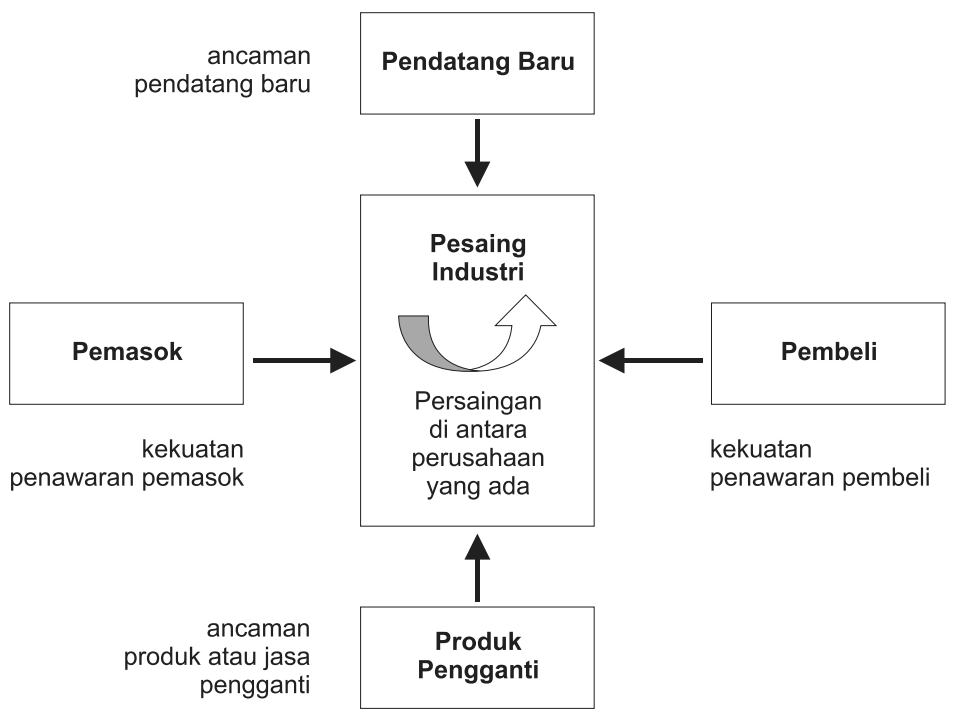

Gambar 1.

Kekuatan-kekuatan yang Memacu Persaingan ${ }^{14}$

Produk pengganti membatasi laba potensial dari industri dengan menetapkan harga yang dapat diberikan oleh perusahaan dalam industri. Makin menarik alternatif harga yang ditawarkan oleh produk pengganti maka makin ketat pembatasan laba industri. Pembeli bersaing dengan industri dengan cara memaksa harga turun, tawar-menawar untuk mutu yang lebih tinggi dan pelayanan yang lebih baik dan semunya mengorbankan kemampuan menghasilkan laba. Kelompok pembeli disebut kuat jika situasi sebagai berikut: kelompok pembeli terpusat, produk yang dibeli dari industri merupakan bagian dari biaya atau pembelian yang cukup besar dari pembeli, produk yang dibeli dari industri adalah produk strandar atau tidak terdiferensiasi, pembeli menghadapi biaya pengalihan yang kecil, pembeli mendapatkan laba yang kecil, pembeli menunjukkan ancaman untuk melakukan integrasi balik, produk industri tidak penting bagi mutu produk atau jasa pembeli dan pembeli mempunyai informasi yang lengkap.

${ }^{14}$ Michael E. Porter, Competitive Strategy..., h. 5. 
Pemasok dapat menggunakan kekuatan tawar-menawar terhadap para peserta industri dengan mengancam akan menaikkan harga atau menurunkan mutu produk atau jasa yang dibeli. Kelompok pemasok dikatakan kuat apabila para pemasok didominasi oleh beberapa perusahaan dan lebih terkonsentrasi ketimbang industri dimana mereka menjual, pemasok tidak menghadapi produk pengganti lain untuk dijual kepada industri, industri tidak merupakan pelanggan yang penting bagi kelompok pemasok, produk pemasok merupakan input penting bagi bisnis pembeli, produk kelompok pemasok terdiferensiasi dan kelompok pemasok memperlihatkan ancaman yang meyakinkan untuk melakukan integrasi maju.

Strategi perusahaan yang secara terus-menerus melakukan penilaian ulang dari ruang lingkup perusahaan, hal ini berhubungan sumber daya yang berharga di pangsa pasar, sumber daya yang dimiliki perusahaan berbeda dengan kekhususan yang dimiliki perusahaan, pada saat dipertukarkan dari sumber daya (seperti uang tunai, berbagai jenis mesin, dan keterampilan umum manajemen) untuk lebih banyak sumber daya khusus (misalnya keahlian dalam disiplin ilmu yang spesifik dan rahasia formula suatu produk) dan sumber daya khusus sering memainkan peran penting dalam mengamankan keunggulan kompetitif. 15

Perusahaan setelah melakukan analisis internal dan eksternal, dapat mengungkapkan serangkaian strategi yang berhubungan dengan peran terbaik untuk produk dan jasa baru, mitra baru, segmen pasar yang baru, segmen-segmen pelanggan yang melakukan perjanjian, dan isu-isu ini akan menjadi fokus dari proses perumusan strategi.

\section{Implementasi The Five Forces strategy pada 'Al-Mumtaz Peduli'}

Manajemen strategi sangat diperlukan dalam sebuah organisasi untuk mengukur kinerja dan menjaga kelangsungan hidup organisasi. Menurut Hunger, manajemen strategis adalah serangkaian keputusan dan tindakan manajerial yang menentukan kinerja perusahaan dalam jangka panjang. Manajemen strategis meliputi pengamatan lingkungan, perumusan strategis (perencanaan strategis atau perencanaan jangka panjang), implementasi

${ }^{15}$ Collis, “Competing on Resources”, h. 149. 
strategi dan evaluasi serta pengendalian. Manajemen strategis menekankan pada pengamatan dan evaluasi peluang dan ancaman lingkungan dengan melihat kekuatan dan kelemahan perusahaan. ${ }^{16}$ Kemudian menurut David, manajemen strategis adalah seni dan ilmu untuk memformulasikan, mengimplementasikan dan mengevaluasi keputusan lintas fungsi yang memungkinkan organisasi dapat mencapai tujuannya. ${ }^{17}$ Manajemen strategi juga menunjukkan suatu proses pengulangan yang tertutup dengan masing-masing bagian dari sistem yang mempengaruhi bagian-bagian lain. Sistem dimulai dengan sebuah proses untuk menyusun strategi. ${ }^{18}$

Perencanaan strategis pada perusahaan sering mendapat kritik disebabkan birokratis, perintah dan pengawasan, tidak fleksibel dan terlalu hirarki, padahal sesungguhnya perencanaan strategis merupakan alat ukur manajemen modern. Menurut Abu Sinn, merumuskan perencanaan strategis sebagai proses penentuan tujuan organisasi, penentuan kebijakan dan program yang diperlukan untuk mencapai sasaran tertentu dalam rangka mencapai tujuan dan penetapan metode yang dibutuhkan untuk menjamin kebijakan dan program strategis itu dilaksanakan sesuai dengan kemampuan dan kondisi. ${ }^{19}$

Menurut Abeng, ada beberapa prinsip dalam perencanaan, yaitu pertama, faktor yang kritis: dalam hamper semua situasi, sejumlah kecil penyebab mempunyai pengaruh yang paling besar pada hasil. Kedua, keengganan untuk berubah: semakin besar perbedaan perubahan yang direncanakan dengan cara-cara yang telah diterima, semakin besar pula potensi keengganan orangorang yang terlibat. Ketiga, kestabilan perencanaan: semakin jauh satu perencanaan ke masa depan, cenderung menjadi tidak pasti. Keempat, keterukuran: semakin terukur tujuan (objective) dan standar yang menyertainya, cenderung semakin efektif usaha untuk mencapainya. ${ }^{20}$ Dalam melakukan perencanaan strategis perusahaan mempertimbangkan hal-hal seperti visi, misi,

\footnotetext{
${ }^{16}$ Fred R David, Strategic Management: Concepts \& Cases (New Jersey: Pearson Education, 2003), h. 5.

17David J. Hunger dan Thomas L. Wheelen, Strategic Management, (New Jersey: Addison-Wesley Publishing, 1996), h. 4.

${ }^{18 H e n r y ~ M i n t z b e r g ~ a n d ~ S u m a n t r a ~ G h o s h a l, ~ T h e ~ S t r a t e g y ~ P r o c e s s: ~ C o n c e p t s, ~ C o n t e x t s, ~ C a s e s, ~(N e w ~}$ Jersey: Pearson Education, 2003), h. 21.

${ }^{19}$ Ahmad Ibrahim Abu Sinn, al-Idarah fi al Islam, (Dubai: al-Matba'ah al-Ashriyah, 1981), h. 58

20 Tanri Abeng, Profesi Manajemen, (Jakarta: Gramedia, 2006), h. 73.
} 
nilai, mengidentifikasi peluang dan ancaman eksternal, menentukan kekuatan dan kelemahan internal, menetapkan tujuan jangka panjang, merumuskan alternatif strategi dan memilih strategi tertentu yang akan dilaksanakan. ${ }^{21}$ Islam juga memandang urgen halhal yang berhubungan dengan perencanaan. Firman Allah:

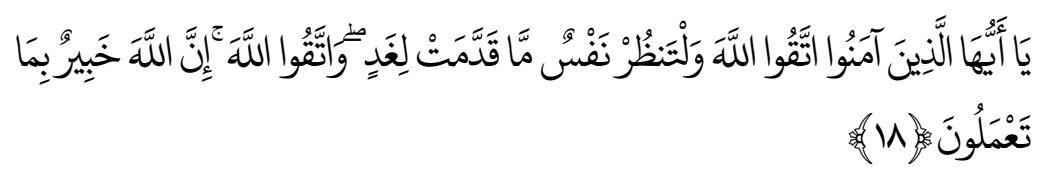

"Hai orang-orang yang beriman, bertakwalah kepada Allah dan rencanakanlah masa depanmu; dan bertakwalah kepada Allah, Sesungguhnya Allah Maha mengetahui apa yang kamu kerjakan."22

Perusahaan yang menghasilkan produk atau jasa, aturan persaingan dicakup didalam lima kekuatan bersaing, yakni masuknya pesaing baru, ancaman dari produk pengganti (substitusi), kekuatan penawaran (tawar-menawar) pembeli, kekuatan penawaran pemasuk dan persaingan diantara pesaingpesaing yang ada. Strategi ini dikenal dengan nama The Five Forces Strategy.

The Five Force Strategy, dalam pendatang baru pada suatu industri membawa kapasitas baru, keinginan untuk merebut pasar, serta seringkali juga sumber daya yang besar. Akibatnya harga dapat menjadi turun atau biaya membesar sehingga mngurangi kemampuan menghasilkan laba. Ada beberapa rintangan masuk bagi pendatang baru, yaitu: skala ekonomis, diferensiasi produk, kebutuhan modal, biaya beralih pemasok, akses kesaluran distribusi, biaya tak menguntungkan terlepas dari skala dan kebijakan pemerintah. Semua perusahaan dalam suatu industri bersaing, dalam arti yang luas, dengan industri-industri yang menghasilkan produk pengganti.

Produk pengganti membatasi laba potensial dari industri dengan menetapkan harga yang dapat diberikan oleh perusahaan dalam industri. Makin menarik alternatif harga yang ditawarkan oleh produk pengganti maka makin ketat pembatasan laba industri. Pembeli bersaing dengan industri dengan cara memaksa harga turun, tawar-menawar untuk mutu yang lebih tinggi dan pe-

${ }^{21}$ David, Strategic Management....., h. 6-7.

${ }^{22}$ QS. al-Hashr [59]:18. 
layanan yang lebih baik dan semunya mengorbankan kemampuan menghasilkan laba. Kelompok pembeli disebut kuat jika situasi sebagai berikut: kelompok pembeli terpusat, produk yang dibeli dari industri merupakan bagian dari biaya atau pembelian yang cukup besar dari pembeli, produk yang dibeli dari industri adalah produk strandar atau tidak terdiferensiasi, pembeli menghadapi biaya pengalihan yang kecil, pembeli mendapatkan laba yang kecil, pembeli menunjukkan ancaman untuk melakukan integrasi balik, produk industri tidak penting bagi mutu produk atau jasa pembeli dan pembeli mempunyai informasi yang lengkap.

Pemasok dapat menggunakan kekuatan tawar-menawar terhadap para peserta industri dengan mengancam akan menaikkan harga atau menurunkan mutu produk atau jasa yang dibeli. Kelompok pemasok dikatakan kuat apabila para pemasok didominasi oleh beberapa perusahaan dan lebih terkonsentrasi ketimbang industri dimana mereka menjual, pemasok tidak menghadapi produk pengganti lain untuk dijual kepada industri, industri tidak merupakan pelanggan yang penting bagi kelompok pemasok, produk pemasok merupakan input penting bagi bisnis pembeli, produk kelompok pemasok terdiferensiasi dan kelompok pemasok memperlihatkan ancaman yang menyakin untuk melakukan integrasi maju.

Rivalitas diantara pesaing yang ada berbentuk pelombaan untuk mendapatkan posisi dengan menggunakan taktik-taktik seperti persaingan harga, perang iklan, introduksi produk, dan meningkatkan pelayanan atau jaminan kepada pelanggan. Persaingan yang tajam merupakan akibat dari sejumlah faktor-faktor struktural yang saling berinteraksi, antara lain: jumlah pesaing yang banyak, pertumbuhan industri yang lambat, biaya tetap yang tinggi, ketiadaan diferensiasi, penambahan kapasitas yang besar, pesaing yang beragam, taruhan strategis yang besar dan hambatan pengunduran diri yang tinggi. ${ }^{23}$

Ada beberapa kesalahan umum yang berhubungan dengan strategi pemanfaatan sumber daya yang biasa dilakukan oleh perusahaan ${ }^{24}$ antara lain; para manajer cenderung melebih-lebihkan pengalihan asset tertentu dan ke-

\footnotetext{
${ }^{23}$ Michael E. Porter, Competitive Strategy...., h. 6-28. Lihat juga Mason A. Carpenter dan Gerand Sander, Strategic Management..., h. 142-153.

${ }^{24}$ Collis, “Competing on Resources”, h. 149-150.
} 
mampuan, manajer melebih-lebihkan kemampuan mereka untuk bersaing dalam industri yang sangat menguntungkan, mengasumsikan bahwa manfaat sumber daya generik, ${ }^{25}$ akan menjadi sumber utama keunggulan kompetitif dalam pangsa pasar yang baru. Perumusan strategi dalam perusahaan dapat membuat sebuah strategi yang berhubungan dengan pangsa pasar, proposisi nilai yang membedakan perusahaan dalam pandangan konsumen, membuat proses kunci untuk perbedaan pada strategi, kapasitas SDM yang diperlukan oleh strategi dan teknologi. 26

Strategi perusahaan yang secara terus-menerus melakukan penilaian ulang dari ruang lingkup perusahaan, hal ini berhubungan sumber daya yang berharga di pangsa pasar, sumber daya yang dimiliki perusahaan berbeda dengan kekhususan yang dimiliki perusahaan, pada saat dipertukarkan dari sumber daya (seperti uang tunai, berbagai jenis mesin, dan keterampilan umum manajemen) untuk lebih banyak sumber daya khusus (misalnya keahlian dalam disiplin ilmu yang spesifik dan rahasia formula suatu produk) dan sumber daya khusus sering memainkan peran penting dalam mengamankan keunggulan kompetitif. ${ }^{27}$

Perusahaan setelah melakukan analisis internal dan eksternal, dapat mengungkapkan serangkaian strategi yang berhubungan dengan peran terbaik untuk produk dan jasa baru, mitra baru, segmen pasar yang baru, segmen-segmen pelanggan yang melakukan perjanjian, dan isu-isu ini akan menjadi fokus dari proses perumusan strategi.

Pendekatan strategi kompetitif yang dilakukan secara konsisten dapat membedakan pemenang dengan pecundang dalam menciptakan samudera biru. Strategi samudra biru atau yang lebih dikenal dengan Blue Ocean Strategy adalah sebuah strategi yang dikemukakan oleh Kim dan Mauborgne, dimana strategi ini menciptakan ruang pasar yang belum ada pesaing, menjadikan kompetisi tidak relevan, menciptakan dan menangkap permintaan baru, men-

\footnotetext{
${ }^{25}$ Sumber daya generik ada tiga yakni: keunggulan biaya, diferensiasi dan fokus. Michael E. Porter, Competitive Advantage..., h. 11.

26Michael E. Porter, “What is Strategy?”, Harvard Business Review, November-December 1996, h. 63. Lihat juga Kaplan and Norton, "Mastering the Management System", h. 66-67. Juga lihat Michael A. Hitt and R. Duane Ireland, Strategic Management: Competitiveness and Globalization, (Ohio: South-Westren College Publishing, 2001), h. 63-65.

${ }^{27}$ Collis, “Competing on Resources", h. 149.
} 
dobrak pertukaran nilai-biaya dan memadukan keseluruhan sistem kegiatan perusahan dalam mengejar diferensiasi dan biaya rendah. ${ }^{28}$

Perusahaan yang perangkap di samudera merah mengikuti pendekatan konvensional, yakni berlomba memenangi kompetisi dengan membangun posisi kokoh dalam tatanan industri yang ada. ${ }^{29}$ Strategi samudera merah dapat diidentifikasi dengan bersaing dalam ruang pasar yang sudah ada, memenangi kompetisi, mengeksploitasi permintaan yang ada, memilih antara nilai dan biaya (value-cost trade off) dan memadukan keseluruhan sistem kegiatan perusahaan dengan pilihan strategis antara diferensiasi atau biaya rendah. ${ }^{30}$ Kreator dari samudera biru, secara mengejutkan tidak menggunakan kompetisi sebagai patokan mereka. Fokus pada saling membandingkan (benchmarking) dan memenangi kompetisi akan mengarah kepada pendekatan imitatif, bukan inovatif, terhadap pasar yang kerap menghasilkan tekanan harga dan komoditas lebih jauh, dimana perusahaan seharusnya berusaha menjadikan kompetisi tidak relevan dengan menawarkan lompatan nilai pada pembeli. ${ }^{31}$ Selanjut menurut Hamel, sukses bagi pemain lama yang mapan dalam industri dan pemain baru bergantung pada kemampuan mereka untuk menghindari kompetisi dan untuk mengonsepsikan ulang model yang ada. ${ }^{32}$ Lihat Lebih lanjut Hamel mengatakan bahwa resep untuk sukses bukan pada pengambilan posisi melawan kompetisi, melainkan pada pengambilan posisi yang menghindari kompetisi. ${ }^{33}$

Analisa eksternal juga meliputi pengujian level industri dari ekonomi industri, seperti Michael Porter's five forces strategy: kekuatan penawaran dari pembeli, kekuatan penawaran dari penyalur, kekuatan barang pengganti,

\footnotetext{
28W. Chan Kim and Renee Mauborgne, Blue Ocean Strategy (Boston: Harvard Business School Press, 2005), h. 19-37.

${ }^{29}$ Peter F. Drucker, Innovation and Entrepreneurship: Practice and Principles (London: William Heinemann, 2001), h. 21.

${ }^{30}$ Kim and Mauborgne, Blue Ocean ..., h. 38.

31W. Chan Kim and Renee Maurbogne, "Value Innovation: The Strategic Logic of High Growth", Harvard Business Review, 75 No. 1, January 1997, h. 102-112.

32 Gary Hamel, “Opinion: Strategy Innovation and the Quest for Value”, Sloan Management Review, 1998, h. 8. http://www.emeraldinsight.com/search.htm, diakses pada tanggal 11 Desember 2014.

${ }^{33}$ Gary Hamel, Leading the Revolution, (Boston: Harvard Business School Press, 2000), h. 54. Lihat juga Clayton M. Christensen and Heiner Bauman, "Disruptive Innovation: for social change”, Harvard Business Review, 84 No. 6, November-December 2006, h. 94-101.
} 
ancaman dari pendatang baru dan persaingan industri. ${ }^{34}$ Strategi ini dikenal dengan nama The Five Force Strategy. 35

Pendatang baru pada suatu industri membawa kapasitas baru, keinginan untuk merebut pasar, serta seringkali juga sumber daya yang besar. Akibatnya harga dapat menjadi turun atau biaya membesar sehingga mengurangi kemampuan menghasilkan laba. Ada beberapa rintangan masuk bagi pendatang baru, ${ }^{36}$ yaitu :

Pertama, skala ekonomis: skala ekonomis menggambarkan turunnya biaya satuan (unit costs) suatu produk apabila volume absolut per periode meningkat. Skala ekonomis menghalangi masuknya pendatang baru dengan memaksa mereka untuk masuk ke skala yang lebih besar ${ }^{37}$ dan mengambil resiko menghadapi reaksi yang keras dari pesaing yang ada atau masuk dengan skala kecil dan beroperasi dengan tingkat biaya yang tidak menguntungkan. Skala ekonomis dapat terjadi pada hampir semua fungsi bisnis dan bidang fungsional.

Kedua, diferensiasi produk: perusahaan tertentu mempunyai identifikasi merek dan kesetiaan pelanggan, yang disebabkan oleh periklanan, pelayanan pelanggan, perbedaan produk dimasa yang lampau atau sekedar karena merupakan perusahaan pertama yang memasuki industri. Diferensiasi menciptakan hambatan masuk dengan memaksa pendatang baru mengeluarkan biaya yang besar untuk mengatasi kesetiaan pelanggan yang ada.

Ketiga, kebutuhan modal: kebutuhan untuk menanamkan sumber daya keuangan yang besar agar dapat bersaing menciptakan hambatan masuk, khususnya jika modal tersebut diperlukan untuk promosi garis depan yang tidak dapat kembali atau untuk kegiatan penelitian dan pengembangan. Modal biasanya dipergunakan untuk fasilitas produksi, persediaan, kredit pelanggan dan mungkin untuk menutup kerugian di saat awal.

Keempat, biaya beralih pemasok: hambatan masuk tercipta dengan adanya biaya beralih pemasok, yaitu biaya satu kali (one time costs) yang harus

\footnotetext{
${ }^{34}$ Michael. E. Porter, "The Five Competitive Forces That Shape Strategy" in Harvard Business Review, January 2008, h. 86-87.

35Michael E. Porter, Competitive Strategy..., h. 4.

36Ibid.., h. 7-12.

37Michael E. Porter, On Competition, (Boston: Harvard Business School Press, 2008), h. 9.
} 
dikeluarkan pembeli bila mana berpindah dari produk pemasok tertentu ke produk pemasok lainnya.

Kelima, akses kesaluran distribusi: hambatan masuk dapat ditimbulkan dengan adanya kebutuhan dari pendatang baru untuk mengamankan distribusi produknya.

Keenam, biaya tak menguntungkan terlepas dari skala: perusahaan yang telah mapan mungkin mempunyai keunggulan biaya yang tidak dapat ditiru oleh pendatang baru yang akan masuk, tanpa memperdulikan besaran biaya dan pencapaian skala ekonomis dari pendatang baru, seperti teknologi produk milik sendiri, penguasaan yang menguntungkan atas bahan baku, lokasi yang menguntungkan, subsidi pemerintah dan kurva belajar atau pengalaman.

Ketujuh, kebijakan pemerintah: pemerintah dapat membatasi kemungkinan masuk kedalam industri dengan peraturan-peraturan. ${ }^{38}$

Al-Mumtaz Peduli melihat terhadap pendatang baru dan organisasi yang berhubungan dengan pengumpulan dan pendayagunaan dari zakat, infaq dan wakaf yang sudah ada, seperti: Badan Amil Zakat Nasional, Dompet Ummat, Rumah Zakat dan LAZ Amanah, merupakan organisasi-organisasi untuk berlomba dalam kebaikan (fastabiq al-khayrāt), sebagai mitra dan bukan kompetitor. Kalau organisasi pengelola zakat lebih dari satu, berarti muzakki punya pilihan, brand image, memacu kinerja dan masing-masing berusaha memberikan yang terbaik.39 $\mathrm{Al}$-Mumtaz Peduli memandang organisasi pengelola zakat yang lain adalah mitra, supaya dapat bersinergi dalam mengentaskan kemiskinan dan menanggulangi bencana serta berbagi ilmu dan pengalaman. Kalau ada LAZ atau pun BAZ yang menganggap LAZ ataupun BAZ sebagai kompetitor adalah haknya masing-masing. Forum Zakat yang beranggotakan lembaga-lembaga 'āmil zakat berusaha memfasilitasi organisasi zakat dalam pengurusan legalitas lembaganya.

Mumtaz Peduli memandang organisasi pengelola zakat yang baru seperti Lembaga 'āmil Zakat NU (LAZNU) Kalimantan Barat dan Lembaga 'āmil Zakat Muhammadiyah (LAZMU) Kalimantan Barat, adalah mitra untuk berlomba-

38Michael E. Porter, Competitive Strategy..., h. 6-12.

${ }^{39}$ Wawancara dengan Direktur Al-Mumtaz Peduli pada tanggal 11 November 2015. 
lomba melakukan kebajikan terutama membantu pemerintah untuk mengentaskan kemiskinan yang ada dan begitu mengakar di masyarakat dan masing-masing LAZ sudah memiliki jamaah sendiri-sendiri serta yang terpenting adalah kepercayaan (trust) dari muzakki. Disamping memang pangsa pasar dari dana yang dapat diserap dari muzakki masih sangat besar. Ini juga menunjukkan bahwa pangsa pasar zakat masih dalam area blue ocean strategy, dimana dalam area ini masih banyak terdapat celah untuk mengumpulkan dana zakat dari muzakki dan mendayagunakannya kepada mustahiq.

Pengumpulan zakat di Singapura dan Malaysia serta Indonesia, terdapat perbedaan yang sangat penting. Di Indonesia peran masyarakat sangat besar dalam pengumpulan dan pendayagunaan zakat dibandingkan dengan Singapura dan Malaysia. Hal ini menunjukkan Pemerintah harus dapat membuat sistem perzakatan yang baik di Indonesia untuk meningkatkan kepercayaan muzakki.

Semua perusahaan dalam suatu industri bersaing, dalam arti yang luas, dengan industri-industri yang menghasilkan produk pengganti. Produk pengganti membatasi laba potensial dari industri dengan menetapkan harga yang dapat diberikan oleh perusahaan dalam industri ${ }^{40}$. Makin menarik alternatif harga yang ditawarkan oleh produk pengganti maka makin ketat pembatasan laba industri. Mengenali produk-produk substitusi adalah persoalan mencari produk lain yang dapat menjalankan fungsi yang sama seperti produk yang sama dalam industri. Ini memang merupakan hal yang sulit dan tugas yang membawa analis kepada bisnis-bisnis yang seolah-olah sangat jauh terpisah dari industrinya. Posisi dalam menghadapi produk pengganti merupakan persoalan tindakan industri secara kolektif. Produk pengganti perlu mendapat perhatian besar adalah produk-produk yang mempunyai kecendrungan untuk memiliki harga atau prestasi yang lebih baik dibandingkan produk industri dan produk-produk yang dihasilkan oleh industri yang berlaba tinggi. ${ }^{41}$

Al-Mumtaz Peduli melihat dalam perspektif terhadap program sejenis, seperti membantu pemerintah mengentaskan kemiskinan yang dihasilkan oleh

${ }^{40}$ Henry Mintzberg and James Brian Quinn, The Strategy Process..., h. 68.

${ }^{41}$ Michael E. Porter, Competitive Strategy...,h. 21-22. 
Al-Mumtaz Peduli namun juga dilakukan oleh organisasi pengelola zakat yang lain. Al-Mumtaz Peduli melihat bahwa kemiskinan di Kalimantan Barat sangat luas dan sangat memerlukan bantuan dari LSM dan Pemerintah karena AlMumtaz Peduli hanya sebuah LSM kemanusiaan dengan dana sangat terbatas. Al-Mumtaz fokus pada anak yatim dan berharap setiap desa ada memiliki satu dai ${ }^{42}$. Berkenaan dengan pendayagunaan dana untuk membantu pemerintah dalam mengentaskan kemiskinan masih terdapat ruang aktivitas yang sangat tinggi. Al-Mumtaz Peduli dapat melakukan sinergi dengan organisasi pengelola zakat yang lainnya, baik badan 'āmil zakat maupun lembaga 'āmil zakat untuk mengentaskan kemiskinan dan mendayagunakannya.

Al-Mumtaz Peduli pada saat pengumpulan dana dari muzakki harus berlomba-lomba dengan organisasi pengelola zakat lain untuk memperoleh kepercayaan muzakki. Selain itu, Al-Mumtaz Peduli juga harus berlomba dengan lembaga pengumpul dana yang lain, seperti masjid-masjid, dana kemanusiaan dan dana amal untuk mengumpulkan dana. Al-Mumtaz Peduli harus selalu melakukan sosialisasi, baik melalui seminar, media massa dan elektronik dalam hal pengumpulan dan pendayagunaan dana ZISWAF dan AlMumtaz selalu meningkatkan pelayanan kepada muzakki dalam bentuk laporan kegiatan dan laporan keuangan berbentuk majalah yang disampaikan per tri wulan. ${ }^{43}$

Kekuatan tawar-menawar dari pembeli. Pembeli bersaing dengan industri dengan cara memaksa harga turun, tawar-menawar untuk mutu yang lebih tinggi dan pelayanan yang lebih baik dan semuanya mengorbankan kemampuan menghasilkan laba ${ }^{44}$. Kelompok pembeli disebut kuat jika situasi sebagai berikut: kelompok pembeli terpusat, produk yang dibeli dari industri merupakan bagian dari biaya atau pembelian yang cukup besar dari pembeli, produk yang dibeli dari industri adalah produk strandar atau tidak terdiferensiasi, pembeli menghadapi biaya pengalihan yang kecil, pembeli mendapatkan laba yang kecil, pembeli menunjukkan ancaman untuk melakukan integrasi

\footnotetext{
42Wawancara dengan Direktur Al-Mumtaz Peduli pada tanggal 11 November 2015.

43Wawancara dengan Direktur Al-Mumtaz Peduli pada tanggal 11 November 2015. 61.

${ }^{44}$ Charles Hill, Gareth Jones, Essentials of Strategic Management (Mason: South-Western, 2008), h.
} 
balik, produk industri tidak penting bagi mutu produk atau jasa pembeli dan pembeli mempunyai informasi yang lengkap. 45

Al-Mumtaz Peduli melayani mustahiq dengan didatangi dan mendatangi mustahiq dengan menggunakan pemetaan, seperti jumlah mustahiq dan masalah yang dihadapi. Hal ini bisa disebabkan oleh bencana, program pelayanan pro aktif. Al-Mumtaz Peduli juga menggunakan jejaring untuk melayani masyarakat, supaya lebih dekat dengan mustahiq dan menghemat biaya dalam program anak asuh, jadup (jatah hidup dhuafa usia lanjut), bea siswa, wakaf qur'an, dhuafa finance dengan sistem qardhul hasan dengan kewajiban menabung dan dianjurkan infaq. ${ }^{46}$

Kekuatan mustahiq dalam posisi tawar-menawar memang sangat lemah, hal ini dikarenakan mustahiq merupakan orang-orang yang perlu mendapat bantuan dalam program pendayagunaan yang dilakukan oleh Al-Mumtaz Peduli baik dalam bentuk komunitas dan individu ${ }^{47}$.

Al-Mumtaz Peduli dalam menjaring muzakki berusaha untuk membangun kepercayaan dari muzakki, hal ini dibuktikan dari dedikasi kerja, kejujuran dan profesional serta aspek public relation yang baik melalui chanelling yang ada, seperti news letter, media cetak dan media elektronik, web site dan menggalang empati dari masyarakat. ${ }^{48}$ Al-Mumtaz Peduli dalam rangka meningkatkan kepercayaan muzakki harus terus melakukan kemitraan dengan muzakki untuk kelangsungan program dan tingkat differensiasi program yang tinggi. Al-Mumtaz Peduli juga memiliki program pemberdayaan ekonomi yang dijalankan secara unik dan belum banyak dilakukan oleh organisasi pengelola zakat lain. Hal ini bisa meningkatkan kepercayaan muzakki kepada Al-Mumtaz Peduli.

Pemasok dapat menggunakan kekuatan tawar-menawar terhadap para peserta industri dengan mengancam akan menaikkan harga atau menurunkan mutu produk atau jasa yang dibeli. Kelompok pemasok dikatakan kuat apabila para pemasok didominasi oleh beberapa perusahaan dan lebih terkonsentrasi

\footnotetext{
45Michael E. Porter, Competitive Strategy..., h. 22-24.

46Wawancara dengan Direktur Al-Mumtaz Peduli pada tanggal 11 November 2015.

47Wawancara dengan Direktur Al-Mumtaz Peduli pada tanggal 11 November 2015.

48Wawancara dengan Direktur Al-Mumtaz Peduli pada tanggal 11 November 2015.
} 
ketimbang industri dimana mereka menjual, ${ }^{49}$ pemasok tidak menghadapi produk pengganti lain untuk dijual kepada industri, industri tidak merupakan pelanggan yang penting bagi kelompok pemasok, produk pemasok merupakan input penting bagi bisnis pembeli, produk kelompok pemasok terdiferensiasi dan kelompok pemasok memperlihatkan ancaman yang menyakin untuk melakukan integrasi maju. Rivalitas diantara pesaing yang ada berbentuk perlombaan untuk mendapatkan posisi dengan menggunakan taktik-taktik seperti persaingan harga, perang iklan, introduksi produk, dan meningkatkan pelayanan atau jaminan kepada pelanggan.

Al-Mumtaz Peduli berhubungan dengan para pemasok dalam rangka pemenuhan kebutuhan organisasi dan program-program yang akan dilaksanakan. Al-Mumtaz Peduli selalu melakukan negosiasi dengan para pemasok untuk mendapatkan harga yang layak dan Al-Mumtaz Peduli sangat menjaga kepercayaan dari muzakki. Misalnya program bantuan beras untuk korban bencana, Al-Mumtaz Peduli melakukan negosiasi dengan supplier-suplier beras untuk mendapatkan harga yang layak. ${ }^{50}$

Persaingan yang tajam merupakan akibat dari sejumlah faktor-faktor struktural yang saling berinteraksi, antara lain: jumlah pesaing yang banyak, pertumbuhan industri yang lambat, biaya tetap yang tinggi, ketiadaan diferensiasi, penambahan kapasitas yang besar, pesaing yang beragam, taruhan strategis yang besar dan hambatan pengunduran diri yang tinggi. ${ }^{51}$ Pendekatan strategi kompetitif yang dilakukan secara konsisten dapat membedakan pemenang dengan pecundang dalam menciptakan samudera biru. Strategi samudra biru atau yang lebih dikenal dengan Blue Ocean Strategy adalah sebuah strategi yang dikemukakan oleh Kim dan Mauborgne, dimana strategi ini menciptakan ruang pasar yang belum ada pesaing, menjadikan kompetisi tidak relevan, menciptakan dan menangkap permintaan baru, mendobrak pertukaran nilai -

\footnotetext{
${ }^{49}$ Svend Hollensen, Global Marketing (New Jersey: Pearson Education, 1998), h. 91.

50Wawancara dengan Direktur Al-Mumtaz Peduli pada tanggal 11 November 2015.

${ }^{51}$ Michael E. Porter, Competitive Strategy..., h. 26-28. Lihat juga Mason A. Carpenter dan Gerand Sander, Strategic Management: A Dynamic Perspective (New Jersey: Pearson Education, 2009), h. 142153.
} 
biaya dan memadukan keseluruhan sistem kegiatan perusahaan dalam mengejar diferensiasi dan biaya rendah. ${ }^{52}$

Perusahaan yang perangkap di samudera merah ${ }^{53}$ mengikuti pendekatan konvensional, yakni berlomba memenangi kompetisi dengan membangun posisi kokoh dalam tatanan industri yang ada. Strategi samudera merah dapat diidentifikasi dengan bersaing dalam ruang pasar yang sudah ada, memenangi kompetisi, mengeksploitasi permintaan yang ada, memilih antara nilai dan biaya (value-cost trade off) dan memadukan keseluruhan sistem kegiatan perusahaan dengan pilihan strategis antara diferensiasi atau biaya rendah. ${ }^{54}$ Kreator dari samudera biru, secara mengejutkan tidak menggunakan kompetisi sebagai patokan mereka. Fokus pada saling membandingkan (benchmarking) dan memenangi kompetisi akan mengarah kepada pendekatan imitatif, bukan inovatif, terhadap pasar yang kerap menghasilkan tekanan harga dan komoditas lebih jauh, dimana perusahaan seharusnya berusaha menjadikan kompetisi tidak relevan dengan menawarkan lompatan nilai pada pembeli.55 Sukses bagi pemain lama yang mapan dalam industri dan pemain baru bergantung pada kemampuan mereka untuk menghindari kompetisi dan untuk mengonsepsikan ulang model yang ada. Resep untuk sukses bukan pada pengambilan posisi melawan kompetisi, melainkan pada pengambilan posisi yang menghindari kompetisi.

Al-Mumtaz Peduli dalam mencari ceruk pangsa pasar, Al-Mumtaz Peduli berusaha untuk berinovatif dan berpikir untuk melihat peluang kebajikan. Salah satu value yang dimiliki oleh Al-Mumtaz Peduli adalah value inovatif supaya Al-Mumtaz Peduli tidak ditinggalkan oleh muzakki. Dalam sinergi antar

\footnotetext{
52Lihat W. Chan Kim dan Renee Mauborgne, Blue Ocean Strategy, h. 19-38.

${ }^{53}$ Lihat ibid., h. 38.

${ }^{54}$ Peter F. Drucker, Innovation and Entrepreneurship: Practice and Principles (London: William Heinemann, 1990), h. 21.

55W. Chan Kim dan Renee Maurbogne, "Value Innovation: The Strategic Logic of High Growth", Harvard Business Review, 75 No. 1, January 1997, h. 102-112. Selanjut menurut Hamel, Lihat Gary Hamel, "Opinion: Strategy Innovation and the Quest for Value", Sloan Management Review, 1998, h. 8. http://www.emeraldinsight. com/search.htm, diakses pada tanggal 9 Desember 2014. Lebih lanjut Hamel mengatakan bahwa Lihat Gary Hamel, Leading the Revolution, (Boston: Harvard Business School Press, 2000), h. 54. Lihat juga Clayton M. Christensen and Heiner Bauman, "Disruptive Innovation: for Social Change", Harvard Business Review, 84 No. 6, November-December 2006, h. 94-101.
} 
LAZ dan BAZ memerlukan fasilitor untuk bisa menerapkan hal ini dan berharap IAIN dapat memfasilitasinya.

\section{Kesimpulan}

Dari pemaparan di atas, dapat disimpulkan bahwa Al-Mumtaz Peduli memandang organisasi pengelola zakat yang lain adalah mitra, supaya dapat bersinergi dalam mengentaskan kemiskinan dan menanggulangi bencana serta berbagi ilmu dan pengalaman. Al-Mumtaz Peduli melihat bahwa kemiskinan di Kalimantan Barat sangat luas dan sangat memerlukan bantuan dari LSM dan Pemerintah karena Al-Mumtaz Peduli hanya sebuah LSM kemanusiaan dengan dana sangat terbatas. Al-Mumtaz fokus pada anak yatim dan berharap setiap desa ada memiliki satu dai. Al-Mumtaz Peduli harus selalu melakukan sosialisasi, baik melalui seminar, media massa dan elektronik dalam hal pengumpulan dan pendayagunaan dana ZISWAF dan Al-Mumtaz selalu meningkatkan pelayanan kepada muzakki dalam bentuk laporan kegiatan dan laporan keuangan berbentuk majalah yang disampaikan per tri wulan. AlMumtaz Peduli melayani mustahiq dengan mendatangi mustahiq serta menggunakan pemetaan; jumlah mustahiq dan masalah yang dihadapi. Hal ini bisa disebabkan oleh bencana, program pelayanan proaktif. Al-Mumtaz Peduli juga menggunakan jejaring untuk melayani masyarakat, supaya lebih dekat dengan mustahiq dan menghemat biaya dalam program anak asuh, jadup (jatah hidup dhuafa usia lanjut), bea siswa, wakaf qur'an, dhuafa finance dengan sistem qardhul hasan dengan kewajiban menabung dan dianjurkan infaq. AlMumtaz Peduli berusaha untuk berinovasi dan berpikir untuk melihat peluang kebajikan.[w] 


\section{BIBLIOGRAFI}

Abeng, Tanri, Profesi Manajemen, Jakarta: Gramedia, 2006.

Abu Sinn, Ahmad Ibrahim, al-Idarah fi al Islam, Dubai: al-Matba'ah al-Ashriyah, 1981.

Adnan, M. Akhyar "Kelembagaan Zakat" dalam Hertanto Widodo dan Teten Kustiawan, Akuntansi \& Manajemen Keuangan untuk Organisasi Pengelola Zakat, Jakarta: IMZ, 2001.

al-Bukhāri, Muhammad bin Isma'il, Sahih al Bukhari, Indonesia: Maktabah Dakhlan, t.th.

Carpenter, Mason A. dan Gerand Sander, Strategic Management: A Dynamic Perspective, New Jersey: Pearson Education, 2009.

Carpenter, Mason A. dan Gerand Sander, Strategic Management: A Dynamic Perspective, New Jersey: Pearson Education, 2009.

Christensen, Clayton M. and Heiner Bauman, "Disruptive Innovation: for social change", Harvard Business Review, Vol. 84 No. 6, November-December 2006.

Collis, David J., "Competing on Resources", Harvard Business Review, 86 No. 6, 2008.

David J. Hunger dan Thomas L. Wheelen, Strategic Management, New Jersey: Addison-Wesley Publishing, 1996.

Direktorat Jenderal Bimbingan Masyarakat Islam Direktorat Pemberdayaan Zakat, Membangun Peradaban Zakat, Jakarta: 2008.

Doa, M. Djamal, Menggagas Pengelolaan Zakat oleh Negara, Jakarta: Nuansa Madani, 2001.

Drucker, Peter F., Innovation and Entrepreneurship: Practice and Principles, London: William Heinemann, 2001.

Fred R, Strategic Management: Concepts \& Cases, New Jersey: Pearson Education, 2003.

Gluck, F.W., S. Hal Kaufman and A.S. Wallack, "The Four Phases of Strategic Management", Journal of Business Strategy, 1992, h. 9-21, diakses pada tanggal 7 Desember 2014. 
Grinzer, P. and P. Mckiernan, "Generating Major Change in Stagnating Companies", Strategic Management Journal, 1990. http://www. interscience.wiley.com/journal/2144/ome/ForAuthors.html. diakses pada tanggal 8 Desember 2014.

Hafidhuddin, Didin dkk., Membangun Peradaban Zakat, Jakarta: IMZ, 2006.

Hamel, Gary, "Opinion: Strategy Innovation and the Quest for Value", Sloan Management Review, 1998, http://www.emeraldinsight.com/ search.htm, diakses pada tanggal 11 Desember 2014.

Hamel, Gary, "Opinion: Strategy Innovation and the Quest for Value", Sloan Management Review, 1998, h. 8. http://www.emeraldinsight. com/search. $\mathrm{htm}$, diakses pada tanggal 9 Desember 2014.

Hamel, Gary, Leading the Revolution, Boston: Harvard Business School Press, 2000.

Hill, Charles dan Gareth Jones, Essentials of Strategic Management, Mason: South-Western, 2008.

Hitt, Michael A. and R. Duane Ireland, Strategic Management: Competitiveness and Globalization, Ohio: South-Westren College Publishing, 2001.

Hollensen, Svend, Global Marketing, New Jersey: Pearson Education, 1998.

Juwaini, Ahmad, "Ketika Zakat ditunaikan Melalui Lembaga" dalam Zakat dan Peran Negara, Jakarta: FOZ, 2006.

Juwaini, Ahmad, "Ketika Zakat ditunaikan Melalui Lembaga", dalam Zakat dan Peran Negara, Jakarta: FOZ, 2006.

Kim, W. Chan and Renee Mauborgne, Blue Ocean Strategy, Boston: Harvard Business School Press, 2005.

Kim, W. Chan and Renee Maurbogne, "Value Innovation: The Strategic Logic of High Growth", Harvard Business Review, 75 No. 1, January 1997.

Mintzberg, Henry and Sumantra Ghoshal, The Strategy Process: Concepts, Contexts, Cases, New Jersey: Pearson Education, 2003.

Mustafa, Ibrāhīm, al Mu'jam al-Wasit\}, Teheran: al-Maktabah al-'Ilmiah, tth.

Porter, Michael E., "What is Strategy?", Harvard Business Review, NovemberDecember 1996.

Porter, Michael E., Competitive Advantage: Creating and Sustaining Superior Performance, Boston: Macmillan Publishers, 1985. 
Porter, Michael E., Competitive Strategy: Techniques for Analyzing Industries and Competitors, Boston: Macmillan Publishers, 1980.

Porter, Michael E., On Competition, Boston: Harvard Business School Press, 2008.

Porter, Michael. E., "The Five Competitive Forces That Shape Strategy", Harvard Business Review, January 2008.

Porter, Michael. E., "The Five Competitive Forces That Shape Strategy" in Harvard Business Review, January 2008.

Qaradāwi, Yūsuf, Fiqh al- al-Zakāh, Bairut: Muassah al-Risālah, tth.

Shihab, M. Quraish, Tafsir al Misbah, Jakarta: Lentera Hati, 2002.

Wawancara dengan Direktur Al-Mumtaz Peduli pada tanggal 11 Nopember 2015.

Zallum, Abd. Al Qadim, al Amwal fi Daulah al Khilafah, terj. Ahmad S. Bogor: Pustaka Tariqul Izzah, 2002.

al-Zuhailly, Wahbah, al-Fiqh al-Islamy wa Adillatuhu, Kairo: Dar Ibnu hazm, 2009. 
